\title{
A new species of Cyphocharax (Characiformes: Curimatidae) with a horizontal color pattern from the rio Tapajós drainage, Amazon basin, Brazil
}

Correspondence: Flávio César Thadeo de Lima fctlima@gmail.com

Submitted December 16, 2019 Accepted March 31, 2020 by Brian Sidlauskas Epub Jun 17, 2020

Online version ISSN 1982-0224 Print version ISSN 1679-6225

Neotrop. Ichthyol. vol. 18, no. 2, Maringá 2020

\section{${ }^{\oplus}$ Gustavo Ceolin Bortolo ${ }^{1}$ and ${ }^{\oplus}$ Flávio César Thadeo de Lima ${ }^{1}$}

A new species of Cyphocharax is described from the rio Mentaí, a tributary of rio Arapiuns, lower rio Tapajós basin, Pará state, Brazil. The new species can be distinguished from its congeners by the combination of a rounded dark blotch at the caudal peduncle and a pattern of horizontal stripes formed by series of conspicuous dark spots situated over the center of the scales on the lateral and dorsolateral surfaces of the body. The new Cyphocharax is compared with similar congeners as C. helleri, C. multilineatus, and C. pantostictos. Comments on the distribution of C. multilineatus are provided.

Keywords: Cyphocharax helleri, Cyphocharax multilineatus, Cyphocharax pantostictos, Rio Arapiuns, Taxonomy.

Uma nova espécie de Cyphocharax é descrita do rio Mentaí, um tributário do rio Arapiuns, bacia do baixo rio Tapajós, estado do Pará, Brasil. A nova espécie se diferencia de todos os congêneres por possuir uma mancha preta arredondada no pedúnculo caudal e um padrão de listras horizontais formadas por manchas escuras conspícuas situadas no centro das escamas laterais e dorsolaterais. $\mathrm{O}$ novo Cyphocharax é comparado com os congêneres mais similares como C. helleri, C. multilineatus e C. pantostictos. Comentários sobre a distribuição de C. multilineatus são fornecidos.

Palavras-chave: Cyphocharax helleri, Cyphocharax multilineatus, Cyphocharax pantostictos, Rio Arapiuns, Taxonomia. 


\section{INTRODUCTION}

The genus Cyphocharax Fowler is widely distributed from southern Central America to southern South America, from Costa Rica to the rio de La Plata in Argentina (Vari, 1992). This large distribution range is partially explained because the species of the genus occurs in many types of water and rivers, from small streams to large rivers, with either clear, white or black waters (Vari et al., 2010; Bortolo et al., 2018). Although the genus is the most speciose among the eight genera of Curimatidae (Vari, 1989) with 44 valid species (Bortolo et al., 2018; Melo et al., 2018), a morphological phylogenetic analysis of the family was unable to recover synapomorphies supporting the monophyly of the genus (Vari, 1989, 1992). A recent supermatrix-based phylogeny for Anostomoidea based on morphological data also failed to recover Cyphocharax as a monophyletic taxon (Dillman et al., 2015), and the same result was obtained after a molecular phylogenetic study of the family Curimatidae (Melo et al., 2018).

Recently, during a collection for the project "Aquatical faunal survey of the lower Amazon" in the tributaries of the rio Arapiuns, one of the major affluent of the rio Tapajós in the lower Amazon basin in Brazil, a distinct Cyphocharax species was found. These specimens are similar to C. pantostictos Vari, Barriga, from the western Amazon basin, however, a comparison of them collected with C. pantostictos revealed that they are a distinct, new taxon. The present contribution aims to describe this new taxon and compare it with the most similar congeners.

\section{MATERIAL AND METHODS}

Morphometric and meristic data were obtained according to Vari (1992). Counts and measurements were taken whenever possible on the left side of specimens. Measurements are presented as percents of standard length (SL), except for subunits of the head, which are given as percents of head length (HL). Frequency of each count is provided in parentheses after the respective count; asterisks indicate holotype values. Counts of vertebrae, unbranched fin rays, and procurrent rays were taken from cleared and stained specimens, prepared according to the protocol of Taylor, Van Dyke (1985). Museum abbreviations follow Sabaj (2019).

\section{RESULTS}

\section{Cyphocharax cramptoni, new species}

urn:lsid:zoobank.org:act:83830F09-3E3A-4D4D-AC98-4F6CC7E68C8D

(Fig. 1; Tab. 1)

Holotype. ZUEC 17124, 49.7 mm SL, Brazil, Pará, Santarém, rio Mentaí (trib. rio Arapiuns), village of Cachoeirinha, 243’28.64”S 55³6’5.60”W, F. C. T. Lima, B. B. Calegari, W. G. R. Crampton and E. Cerdeira, 26-27 Nov 2015. 
Paratypes. MCP 54224, 2, 32.2-34.7 mm SL; MPEG 38861, 2, 26.0-29.8 mm SL; UF 243981, 2, 31.2-41.0 mm SL; ZUEC 12071, 4, 22.9-30.2 mm SL (24.4 mm SL c\&s), same data as holotype.

Diagnosis. Cyphocharax cramptoni is distinguished from most congeners, except $C$. helleri (Steindachner), C. multilineatus (Myers), and C. pantostictos by possessing series of horizontal stripes along the body on the lateral and dorsolateral surfaces of the body ( $v$ s. absence of a similar pattern in the remaining Cyphocharax species). It can be distinguished from Cyphocharax helleri and C. multilineatus by possessing horizontal stripes formed by series of conspicuous dark spots situated over the center of the scales on the lateral and dorsolateral surfaces of the body ( $v$ s. stripes along the areas of overlap of horizontal rows of scales along the body in C. helleri and C. multilineatus). It can be additionally distinguished from C. multilineatus by possessing a rounded dark blotch at the caudal peduncle ( $v s$. absence) and longitudinal dark stripes straight ( $v s$. wavy). Cyphocharax cramptoni is distinguished from C. pantostictos by the presence of a rounded dark blotch at the caudal peduncle ( $v s$. presence of a narrow, midlateral, horizontally
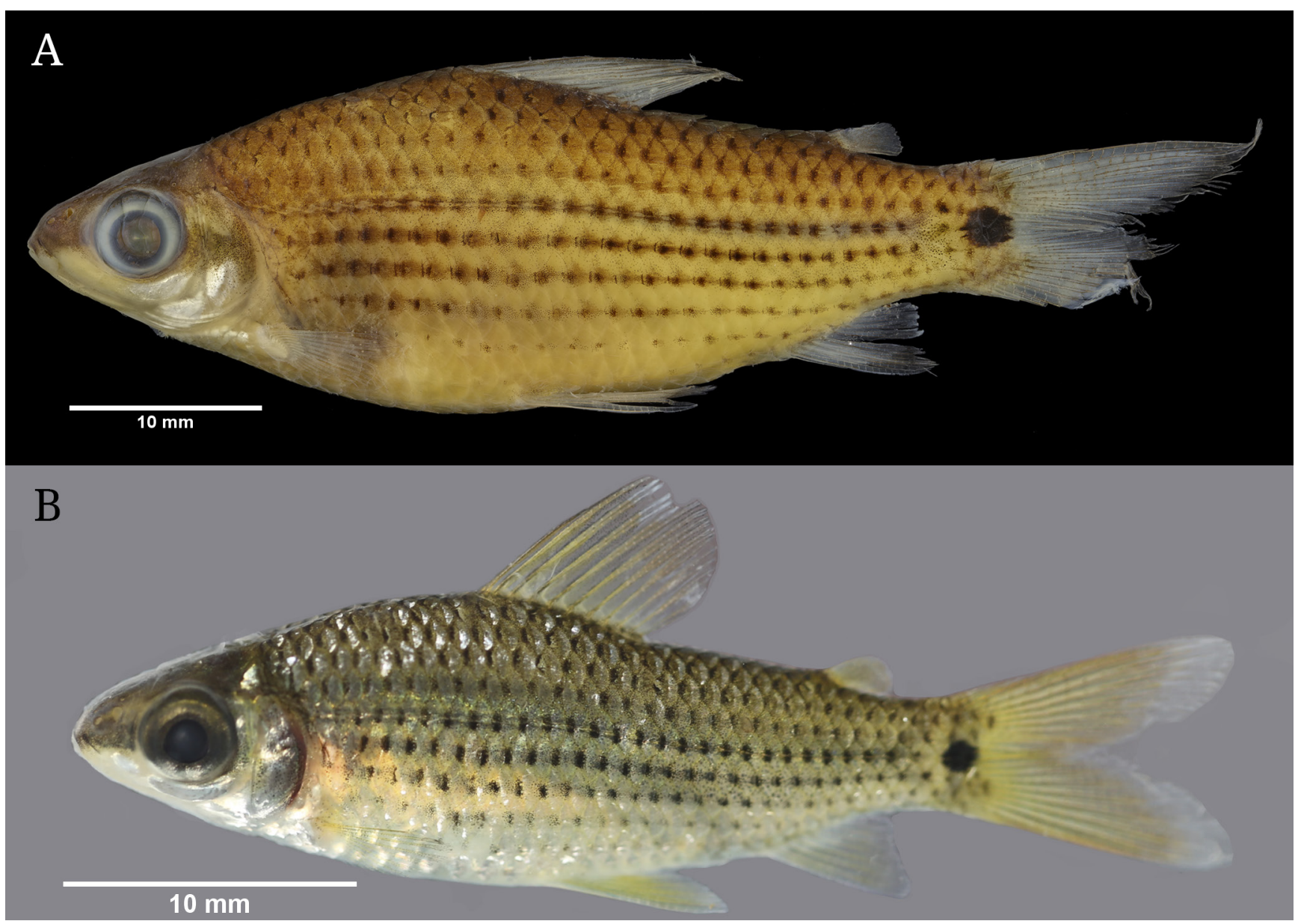

FIGURE 1 I Cyphocharax cramptoni; A. holotype, ZUE C 17124, 49.7 mm SL, Brazil, Pará, Santarém, rio Mentaí; B. Living specimen, ZUEC 12071, $30.2 \mathrm{~mm} \mathrm{SL}$, same data as holotype. 
elongate dark stripe on the caudal peduncle), by possessing a postorbital stripe ( $v s$. absence), by possessing a smaller length of postorbital portion of head (28-37\% HL vs. $42-46 \%$ of HL, respectively), and a larger orbital diameter (38-45\% of HL vs. $24-33 \%$ of $\mathrm{HL}$, respectively).

Description. Morphometric data of eleven specimens is presented in Tab. 1. Body moderately elongate, somewhat compressed laterally. Dorsal profile of head slightly convex from upper lip to vertical line through posterior nostril; straight or slightly convex from that point to tip of supraoccipital spine. Dorsal profile of body straight or smoothly curved from tip of supraoccipital spine to dorsal-fin origin; dorsal-fin base straight to slightly convex in smaller individuals and posteroventrally slanted; straight from base of last dorsal-fin ray to adipose fin; slightly concave from adipose fin to first procurrent ray. Ventral profile of body gently convex from tip of lower jaw to caudal peduncle. Ventral profile of caudal peduncle slightly concave. Prepelvic region somewhat flattened transversely, with median series of scales not enlarged relative to those on adjoining portions of body.

Dorsal fin pointed, with distal margin straight and first and second branched rays longest. Pectoral-fin profile pointed. Tip of adpressed pectoral fin falls four or five scales short of vertical through pelvic-fin origin. Pelvic-fin profile pointed. Tip of adpressed pelvic fin falls one or two scales short of anus. Caudal fin forked, with lobe tips pointed. Adipose fin well developed. Anal fin emarginate with first branched ray longest and about three times length of ultimate ray.

Head profile anteriorly pointed overall from lateral view but rounded in region of mouth and snout. Upper jaw longer than lower jaw, with mouth slightly subterminal. Nostrils very close to each other; anterior circular to ovoid, posterior crescent-shaped with aperture closed by thin flap of skin separating nostrils. Adipose eyelid well developed and extending posteriorly onto anterodorsal portion of opercle. Smaller specimens (22.9-34.7 $\mathrm{mm} \mathrm{SL}$ ) with central aperture in adipose eyelid rounded, approximately corresponding to limits of pupil. Larger specimens ( $49.7 \mathrm{~mm} \mathrm{SL}$ ) with opening vertically-ovoid, with eyelid overlapping anterior and posterior portions of pupil.

All scales of lateral line pored, with primary laterosensory canal straight. Pored lateralline scales from supracleithrum to hypural joint $28(1), 29^{\star}(4)$ or $30(5)$. Pored scales on basal portions of caudal fin posterior to hypural joint $2(6)$ or $3^{\star}(2)$. Scales in transverse series from dorsal-fin origin to lateral line $5^{\star}(11)$. Scales in transverse series from anal-fin origin to lateral line $4^{\star}(11)$. Scales in transverse series from pelvic-fin origin to lateral line $5^{\star}(11)$. Scales between anus and anal-fin origin $1^{\star}(8)$ or $2(2)$. Middorsal series of scales from rear of supraoccipital spine to dorsal-fin origin $8(1), 9(7)$ or $10^{\star}(3)$. Anterior scales similar in size to those on posterior portion of caudal peduncle; scale size slightly decreasing in size distally.

Dorsal-fin rays iii, $9^{\star}(10)$ or iii,10(1), first unbranched ray very short. Anal-fin rays iii, $7^{\star}(9)$, iii, $8(2)$ first ray very short. Pelvic-fin rays $i, 7, i^{\star}(11)$. Pectoral-fin rays $13^{\star}(6)$, $14(4)$ or 15(1). Ventral procurrent rays 7(1). Dorsal procurrent rays 7(1). Total vertebrae 31(1).

Coloration in alcohol. Overall body ground coloration tan, darker on dorsal portion of body and head, especially in larger specimens. Dark postorbital stripe 
TABLE 1 I Morphometric data for Cyphocharax cramptoni $\mathrm{N}=11$ (number of specimens measured). $\mathrm{SD}=$ standard deviation.

\begin{tabular}{|r|c|c|c|}
\hline & Holotype & Range & Mean \pm SD \\
\hline Standard length (mm) & 49.7 & $22.9-49.7$ & 31.8 \\
\hline Percentage of standard length & & & $35.6 \pm 1.4$ \\
\hline Greatest body depth & 36.4 & $34.1-38.3$ & $50.4 \pm 1.2$ \\
\hline Snout to dorsal-fin origin & 49.3 & $48.1-52.0$ & $55.8 \pm 1.7$ \\
\hline Snout to anal-fin origin & 79.5 & $53.2-58.8$ & $80.3 \pm 1.5$ \\
\hline Snout to anus & 75.7 & $77.7-82.1$ & $76.6 \pm 2.1$ \\
\hline Caudal peduncle depth & 13.1 & $72.9-80.1$ & $55.6 \pm 1.8$ \\
\hline Pectoral-fin length & 14.7 & $52.5-58.6$ & $12.6 \pm 0.5$ \\
\hline Pelvic-fin length & 21.1 & $11.9-13.6$ & $16.0 \pm 1.4$ \\
\hline Dorsal-fin length & 28.6 & $13.5-17.9$ & $22.9 \pm 1.4$ \\
\hline Head length & 26.6 & $20.1-24.6$ & $29.0 \pm 0.7$ \\
\hline Porcin origin to hypural joint & 56.3 & $28.2-30.0$ & $29.1 \pm 1.8$ \\
\hline Onterorbital width & 38.6 & $26.1-32.4$ & \\
\hline
\end{tabular}

hourglass-shaped formed by highly concentrated dark chromatophores situated over opercle. Scales on lateral and dorsal surfaces of body with dark patch of pigmentation at base and center of each scale, fading towards distal portion; spots more developed at midlateral portion of body; larger specimens with blurred portion of spots darker, connecting dots, giving aspect of horizontal stripes passing through scales on lateral portion of body; smaller specimens with spots of each scale isolated, with less intense posterior blur. Spots arranged in nine horizontal series, dorsal and ventral series of dark spots less apparent in smaller specimens. Series of dark spots on scales less developed posteriorly on scale rows ventral of lateral line; very poorly developed in series starting immediately posterodorsal to origin of pectoral fin. Intense dark spots also progressively less pronounced in horizontal series dorsal to lateral line. Small, rounded, conspicuous spot on midlateral surface of caudal peduncle, extending to end of caudal peduncle but not onto caudal fin. All fins hyaline, with few, scattered dark chromatophores.

Coloration in life. Based on a picture of a living specimen taken in field (Fig. 1B). Overall coloration glossy grey, with a greenish tint on dorsal and lateral surfaces of body. Top of head and snout dark grey. Abdominal area and lower surface of head whitish to silvery. Discrete, relatively broad longitudinal dark stripe running from snout tip to posterior portion of eye. Postorbital region with a greenish metallic tint; opercle plumbeous. Fins with a light-yellow pigmentation over rays, fading towards tips. Dark pigmentation as in preserved specimens. 
Distribution. Cyphocharax cramptoni is only known from the Rio Mentaí, a tributary of rio Arapiuns, lower rio Tapajós basin, Amazon basin, Pará, Brazil (Fig. 2).

Habitat notes. The rio Mentaí, at the type locality of Cyphocharax cramptoni, is a small 10-15 meters wide clearwater river with a bottom composed mainly of sand, submerged rocks, and abundant submerged vegetation at the shoreline and shallower portions. Water parameters at the time of collecting were: water temperature $26.9^{\circ} \mathrm{C}$, conductivity $11.8 \mu \mathrm{s} / \mathrm{cm}, \mathrm{pH} 4.2$, dissolved oxygen $5.5 \mathrm{mg} /$, and turbidity 0.72 .

Etymology. The new species is named in honor to William G. R. Crampton, in recognition of his important contributions to the knowledge of the fishes from the Amazon basin. A name in the genitive case.

Conservation Status. Cyphocharax cramptoni is only known from few specimens from a single locality in the rio Mentaí, which together with the rio Maró and rio Aruã, form the rio Arapiuns. It seems very likely that the species is more widespread in the basin

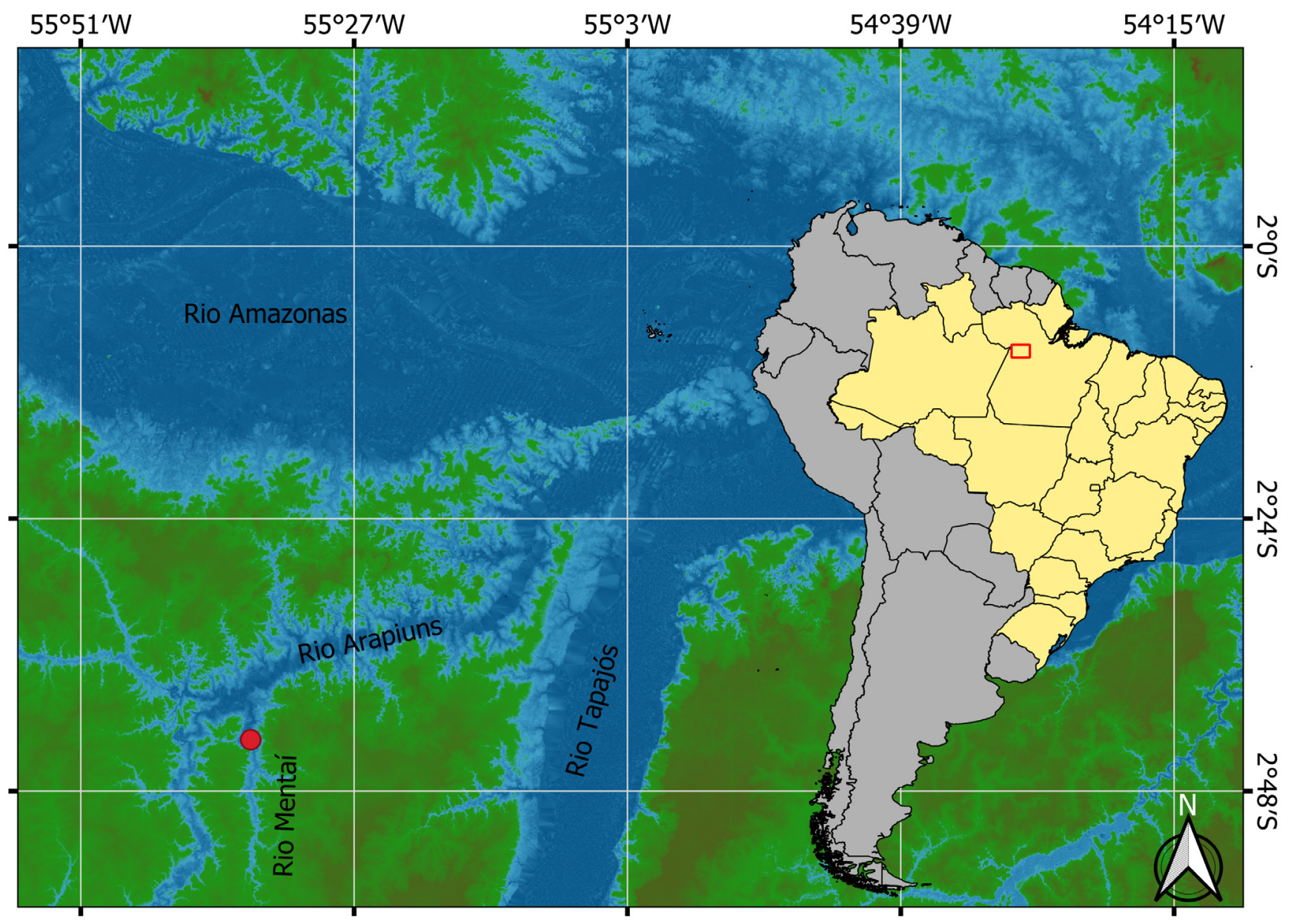

FIGURE 2 I Map of the lower Tapajós basin and its confluence with rio Amazonas showing the distribution of Cyphocharax cramptoni. The red dot indicates the type locality. 
and perhaps, adjacent portions of the Amazon basin, although more collecting efforts are necessary. The rio Arapiuns basin has been subject to some anthropogenic impacts such as bauxite mining in the rio Aruã basin and selective logging, but these impacts do not seem to have caused major disturbances on the local aquatic environments. The type locality lies within the Reserva Extrativista Tapajós-Arapiuns, which afford some legal protection to the area. Since this is the only information currently available for the species, we recommend the status Least Concern (LC) following IUCN's criteria (IUCN Standards and Petititon Subcommittee, 2019).

\section{DISCUSSION}

The new species shares the presence of series of horizontal stripes across the body with the congeners Cyphocharax multilineatus, C. helleri, and C. pantostictos. However, as noted in the diagnosis, C. cramptoni can be distinguished from all these species by its unique combination of presence of horizontal stripes formed by series of conspicuous dark spots situated over the center of the scales and a large rounded spot at the end of the caudal peduncle.

The species most similar overall to Cyphocharax cramptoni, C. pantostictos, shares the pattern of horizontal series of dark spots aligned along the center of the body scales (Vari, Barriga, 1990). The presence of an unbranched last pelvic-fin ray is another character apparently only shared between these two species in the entire genus. This feature was first reported by Vari (1992: 30) as occurring in part of the specimens of C. pantostictos, while others possess a branched last pelvic-fin ray, typical for the genus. The last pelvic-fin ray is unbranched in all known specimens of $C$. cramptoni. In the specimens of $C$. pantostictos examined in the present study, eight presented a branched last pelvic-fin ray and two possessed it unbranched. The most conspicuous difference between the two species is the shape of the dark pigmentation on the caudal peduncle. Cyphocharax cramptoni possess a dark rounded spot, while C. pantostictos has an elongated, relatively thick stripe. However, the smallest specimen of C. pantostictos examined herein (ZUEC 17137, 48.8 mm SL; Fig. 3A) lacks the thick stripe whereas even the smallest C. cramptoni analyzed in this paper (ZUEC 12071, $22.9 \mathrm{~mm} \mathrm{SL}$ ) possess the dark, rounded caudal peduncle spot. Cyphocharax pantostictos is known from the western Amazon basin in Ecuador, Peru (Vari, 1992) and Colombia (DoNascimiento et al., 2017) and is herein reported for the Tefé area in the rio Solimões, Amazonas, Brazil (ZUEC 15372), extending its distribution considerably to the east.

A congener with a similar color pattern to Cyphocharax cramptoni, C. multilineatus (Fig. 3B) was collected syntopically with the new species in the rio Mentaí (MCP 54223) and is also known from the neighboring rio Aruã, another tributary of the rio Arapiuns (MPEG 25991; MPEG 30316; MPEG 34869). Cyphocharax multilineatus was previously known from the upper rio Negro and upper río Orinoco basins (Vari, 1992; Lima et al., 2005). Freitas et al. (2018) recorded the species for the rio Caxiuanã, a blackwater system in the lower Amazon basin. Dagosta, de Pinna (2019; 41-44) identified a distribution pattern called "Central Blackwater Amazon" to describe species with ranges in the blackwater systems of the central Amazon. Some of the species are restricted to the rio Negro/Orinoco and Tapajós basin as Astyanax ajuricaba 
Marinho, Lima, and Charax condei Géry, Knöppel, while others also occur in some adjacent blackwater systems as Leporinus altipinnis Borodin, and Heterocharax virgulatus Toledo-Piza. Cyphocharax multilineatus apparently shares a similar distribution pattern with those taxa, but, as mentioned above, it occurs in blackwaters even further east, at the rio Caxiuanã.

Although Vari (1992, p. 124) hypothesized that Cyphocharax helleri and C. multilineatus were closely related since they share the same pattern of stripes along the areas of overlap of horizontal rows of scales, these species were not recovered as sister taxa (Melo et al., 2018). However, Melo et al. (2018) did not include Cyphocharax pantostictos, so the position of this species in the clade remains unknown. It is likely that C. pantostictos and C. cramptoni are closely related species since they share two unique characters within the genus. On the other hand, C. cramptoni shares with C. multilineatus the presence of a postorbital stripe, which is absent in C. helleri and C. pantostictos. Cyphocharax cramptoni also shares with $C$. helleri the presence of a rounded caudal-peduncle blotch, which is absent in C. multilineatus and C. pantostictos. Sidlauskas et al. (2012) reported that the

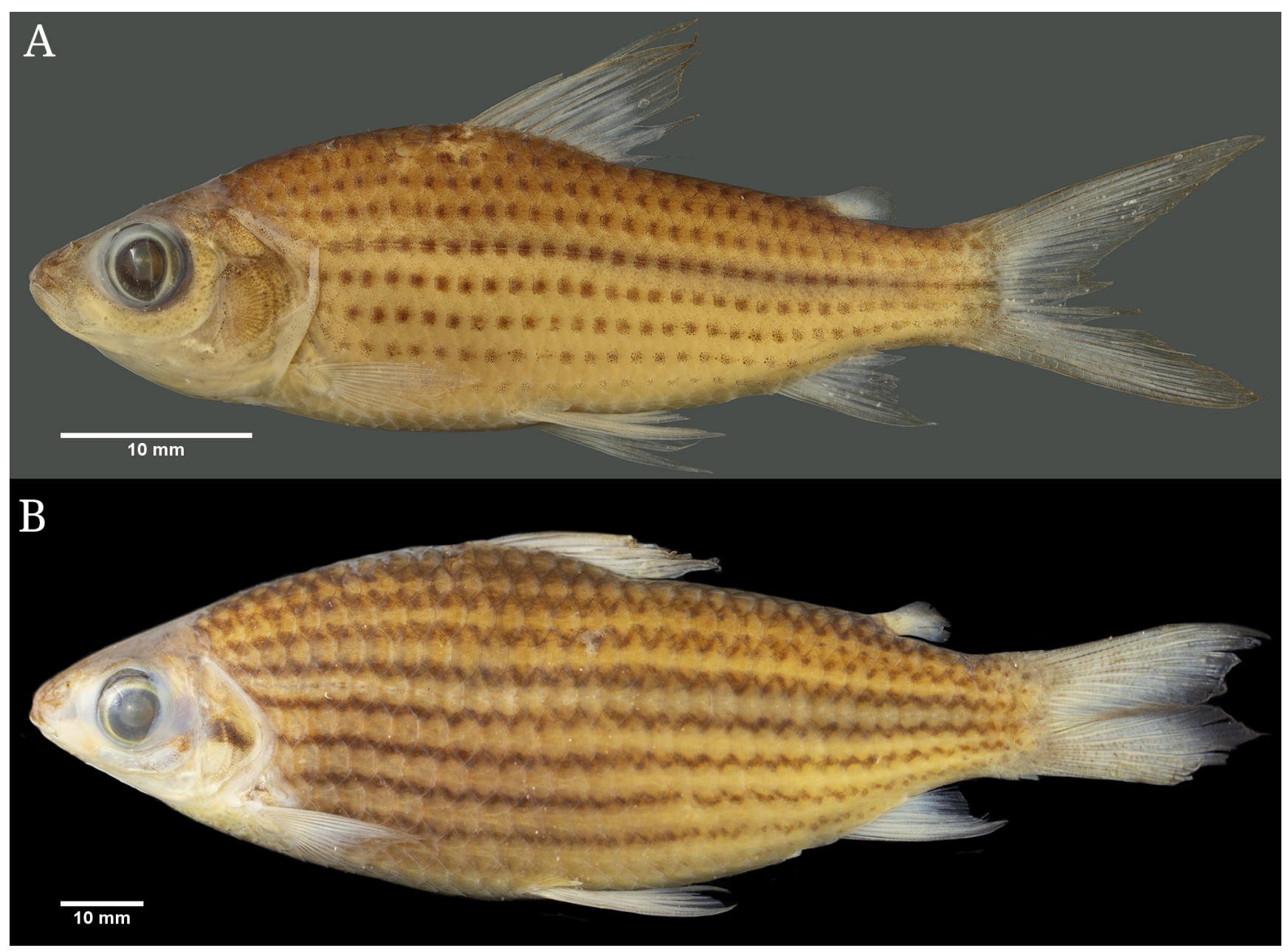

FIGURE 3 I A. Cyphocharax pantostictos, ZUEC 17137, 48.8 mm SL, Peru, Loreto, río Itaya basin; B. Cyphocharax multilineatus, MCP 54223, 116.3 mm SL, Brazil, Pará, Santarém, rio Mentaí. 
longitudinal stripes in C. helleri may vary in intensity, being in some instances very pale. A more inclusive phylogeny of Cyphocharax including all striped species will be necessary to test their putative close relationship as well as their relationships within the genus.

Comparative material examined: Cyphocharax helleri: Brazil: MZUSP 31732, 1, 102.9 mm SL; MZUSP 101738, 2, 59.7-64.0 mm SL; MZUSP 102273, 1, 43.9 mm SL. Suriname: MZUSP 21365, 1, 69.7 mm SL. Cyphocharax multilineatus: Brazil: MCP 54223, 1, 116.3 mm SL; MPEG 8618, 1; MPEG 8700, 1; MPEG 25991, 2; MPEG 30316, 2; MPEG 34869, 11; ZUEC 16234, 3, 13.8-49.7 mm SL. Colombia: MZUSP 85024, 31, 46.5-86.5 mm SL. Cyphocharax pantostictos: Brazil: ZUEC 15372, 7, 88.9-107.2 mm SL. Peru: MZUSP 85581, 1, 66 mm SL; UF 243980, 1, 118.5 mm SL; ZUEC 17137, 1, 48.8 mm SL. Cyphocharax vanderi: Brazil: ZUEC 4280, 1, 34.7 mm SL; ZUEC 4819, 1, $61.7 \mathrm{~mm}$ SL.

\section{ACKNOWLEDGEMENTS}

All material of the new species was collected during an expedition of the project "Aquatic Faunal Survey of the Lower Amazon" (NSF Grant DEB-1146734 to William G. R. Crampton). The second author is grateful to William G.R. Crampton, Bárbara B. Calegari, and Elias Cerdeira for the help in the field. We are grateful to Osvaldo T. Oyakawa, Alessio Datovo, and Michel Gianeti (MZUSP), and Wolmar B. Wosiacki and Alberto Akama (MPEG) for access to specimens under their care. Figures $1 \mathrm{~A}$ and 4A were prepared by Eduardo G. Baena. The authors were funded by CAPES (GCB) and FAPESP (FCTL; grants \# 2011/51532-7 and 2013/20936-0).

\section{REFERENCES}

- Bortolo GC, Lima FCT, Melo BF. A new Cyphocharax from the Lower Rio Tapajós, Amazon Basin, Brazil (Characiformes: Curimatidae). Copeia, 2018; 106(2):346-52. http://doi.org/10.1643/CI-17-656

- Dagosta FCP, De Pinna M. The Fishes of The Amazon: Distribution and Biogeographical Patterns, with a Comprehensive List of Species. B Am Mus Nat Hist, 2019; 431:1-163. https://doi. org/10.1206/0003-0090.431.1.1

- Dillman CB, Sidlauskas BL, Vari RP. A morphological supermatrix-based phylogeny for the Neotropical fish superfamily Anostomoidea (Ostariophysi: Characiformes): phylogeny, missing data and homoplasy. Cladistics, 2015; 32(3):1-21. http://doi.org/10.1111/cla.12127
- DoNascimiento C, Herrera-Collazos EE, Herrera-R. GA, Ortega-Lara A, Villa-Navarro FA, Usma Oviedo JS, Maldonado-Ocampo JA. Checklist of the freshwater fishes of Colombia: a Darwin core alternative to the updating problem. Zookeys, 2017; 708:25-138. http://doi. org/10.3897/zookeys.708.13897

- Freitas TMS, Prudente BS, Freitas DTH, Benone NL, Leo H, Dutra GM, Montag LFA. Fishes of Caxiuanã National Forest: 20 years (1993 to 2012) of sampling in a protected area in the Eastern Amazon. Boletim do Museu Paraense Emílio Goeldi. Ciências Naturais. 2018; 13(2):185-204. 


\section{- IUCN Standards and Petitions}

Committee. 2019. Guidelines for Using the IUCN Red List Categories and Criteria. Version 14. Prepared by the Standards and Petitions Committee. Available from http://www.iucnredlist.org/documents/ RedListGuidelines.pdf

- Lima FCT, Ramos L, Barreto T, Cabalzar A, Tenório G, Barbosa A, Tenório F, Resende AS, Lopes MC. Peixes do alto Tiquié: ictiologia e conhecimento dos tuyuka e dos tukano. In: A. Cabalzar (org.), Peixes e gente no alto rio Tiquié. Conhecimentos tukano-tuyuka. Ictiologia, etnologia. Instituto Socioambiental, São Paulo; 2005. p.111-282.

- Melo BF, Sidlauskas BL, Hoekzema K, Vari RP, Dillman CB, Oliveira C. Molecular phylogenetics of Neotropical detritivorous fishes of the Family Curimatidae (Teleostei: Characiformes). Mol Phylogenet Evol. 2018; 127:800-12.

- Sidlauskas BL, Vari RP. Diversity and distribution of anostomoid fishes (Teleostei: Characiformes) throughout the Guianas. Cybium. 2012; 36(1):71-103. https://doi.org/10.26028/ cybium/2012-361-008
- Taylor WR, Van Dyke GC. Revised procedures for staining and clearing small fishes and other vertebrates for bone and cartilage study. Cybium, 1985; 9(2):107-19.

- Vari RP. A phylogenetic study of the Neotropical characiform family Curimatidae (Pisces: Ostariophysi). Smithson Contrib Zool. 1989; 471:1-71. https://doi.org/10.5479/si.00810282.471

- Vari RP, Barriga RS. Cyphocharax pantostictos, a New Curimatid (Pisces, Ostariophysi, Characiforms, Curimatidae) from the Western Portions of the Amazon Basin. Proc Biol Soc Wash. 1990; 103(3):550-57.

- Vari RP. Systematics of the Neotropical characiform genus Cyphocharax Fowler (Pisces: Ostariophysi). Smithson Contrib Zool. 1992; 529:1-137. https://doi. org/10.5479/si.00810282.529

- Vari RP, Zanata AM, Camelier P. New species of Cyphocharax (Ostariophysi: Characiformes: Curimatidae) from the Rio de Contas drainage, Bahia, Brazil. Copeia. 2010; 3:382-87. https://doi.org/10.1643/CI09-140

\section{Neotropical lchthyology}

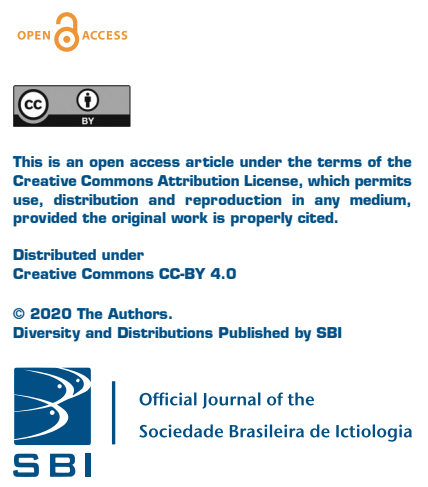

\section{AUTHOR'S CONTRIBUTION}

Gustavo Ceolin Bortolo: Formal analysis, Investigation, Methodology, Software, Visualization, Writingoriginal draft, Writing-review \& editing.

Flávio César Thadeo de Lima: Conceptualization, Data curation, Funding acquisition, Project administration, Resources, Supervision, Validation, Visualization, Writing-review \& editing.

\section{ETHICAL STATEMENT}

Not applicable.

\section{COMPETING INTERESTS}

The authors declare no competing interests.

\section{HOW TO CITE THIS ARTICLE}

- Bortolo GC, de Lima FCT. A new species of Cyphocharax (Characiformes: Curimatidae) with a horizontal color pattern from the rio Tapajós drainage, Amazon basin, Brazil. Neotrop Ichthyol. 2020; 18(2):e190135. https://doi.org/10.1590/1982-0224-2019-0135 